\title{
AFRICAN MISTLETOES (LORANTHACEAE); ETHNOPHARMACOLOGY, CHEMISTRY AND MEDICINAL VALUES: AN UPDATE
}

\author{
${ }^{193}$ Simeon K. Adesina, ${ }^{2}$ H. C. Illoh, ${ }^{3}$ Imoh I. Johnny and ${ }^{3}$ Imo E. Jacobs
}

${ }^{1}$ Drug Research and Production Unit, Faculty of Pharmacy and ${ }^{2}$ Department of Botany, Faculty of Science, Obafemi Awolowo University, Ile-Ife, Osun State, Nigeria. ${ }^{3}$ Department of Pharmacognosy and Natural Medicine, Faculty of Pharmacy, University of Uyo, Uyo, Akwa Ibom State, Nigeria

E-mail: $\underline{\text { simkol2000@yahoo.com }}$

\begin{abstract}
Mistletoes of the Loranthaceae and Viscaceae are hemi-parasitic plants and their preparations in the form of injectable extracts, infusions, tinctures, fluid extracts or tea bags are widely used in various cultures in almost every continent to treat or manage various health problems including hypertension, diabetes mellitus, inflammatory conditions, irregular menstruations, menopause, epilepsy, arthritis, cancer, etc. The medicinal values of some species of Mistletoes (Loranthaceae) growing in the West African sub-region have been reviewed along with some considerations of their chemistries and local uses. These have been compared with Mistletoes (Loranthaceae and Viscaceae) growing elsewhere in Europe and Asia. This review has attempted to update our knowledge on the values of these hemi-parasites which belong to the genera - Globimetula, Phragmanthera, Agelanthus and Tapinanthus, and which have, for years, been seen as only devastating and notorious plants. They are also seen as epiphyting economic, ornamental and medicinal plants. The hemi-parasitic plants (Mistletoes) are not well understood as very little is known about their biology (taxonomy, host/plant relationship, ecology, toxicology, physiological characteristics, etc.) and chemistry (chemical constituents' profile). Some pharmacological studies carried out on the various crude alcoholic extracts and purified fractions have, however, revealed that mistletoes showed hypotensive, hypoglycaemic, antilipidaemic, anti-oxidative, anti-inflammatory, antimicrobial, etc. effects and were non-toxic in experimental animals at the doses used. The findings showed that mistletoes can be very useful as medicinal agents in ameliorating health problems such as diabetes mellitus, hypertension, arthritis, pain, cancer and a host of other ailments if properly studied and developed.
\end{abstract}

Key Words: Mistletoes, Loranthaceae, Viscaceae, Botany, Ethnopharmacology, Chemistry, Pharmacological Effects, Medicinal values

\section{Introduction}

Mistletoe, with the common name(s) - bird lime, all heal, devil's fuge, Iscador, etc. - is a general term for woody shoot parasites in several plant families, especially Loranthaceae and Viscaceae (Burkill, 1985, Parker and Riches, 1993, Polhill and Wiens, 1998) and most genera of African mistletoes belong to the family Loranthaceae (Polhill and Wiens, 1998).

Seven genera of the Loranthaceae - Helixanthera, Berhautia, Englerina, Globimetula, Agelanthus, Tapinanthus and Phragmanthera - with about five dozen or more species are recognised in West Africa (Burkill, 1985) and the group term, mistletoe, is used for all these species. Besides, the host plant is considered as important as the mistletoe since distinction is made between hosts and not between mistletoes, implying that the biology of the Loranthaceae species is not clearly understood. This has implications on the medicinal use of the plant species in the Loranthaceae.

In West Africa, mistletoes are found on many tree crops of economic importance including the shea butter tree (Vitellaria paradoxa Gaertn. f.), the neem tree (Azadirachta indica L.), citrus species, especially sweet orange (Citrus sinensis L.) and grape (Citrus paradisi L.), cocoa (Theobroma cacao L.) and rubber (Hevea brasiliensis Muell Arg) (Bright and Okusanya, 1998; Overfield et al., 1998; Gill and Onyibe, 1990; Begho et al., 2007). Various species of these hemi-parasitic plants growing on other economic, medicinal and cultivated trees such as the hog-plum (Spondias monbin L.), the brimstone tree (Morinda lucida Benth). the African Rauwolfia (Rauwolfia vomitoria Afzel), the kola-nut tree (Cola nitida Vent. Schot and Endl.), the sand paper tree (Ficus exasperata Vahl), teak (Tectonia grandis L. f.), the bread fruit tree (Artocarpus utilis Parkinson), forest trees such as Terminalia glaucescens Planch ex Benth, Ficus mucuso (Welw.) ex Fichalo, etc. have also been found. These findings seem to lend credence and support to the Yoruba adage which sees the Mistletoes as having no roots but that they (mistletoes) are related to all tree hosts.

The typical farmer or gardener sees mistletoes as notorious and devastating parasites which pose serious losses to economically-valuable fruit trees like cocoa, rubber, kola-nut, and medicinal plants like Morinda lucida and Rauwolfia vomitoria whether growing in wild forests, gardens or orchards (Sridhar and Rao, 1978, Zewdie and Eshetu, 1993, Bright and Okusanya, 1998, Overfield et al., 1998 and Jiofack et al., 2010). Very often, host trees that have lots of mistletoes suffer from them as the triumph of mistletoes lead to poor growth and productivity and eventual death of such host plants, especially during unfavourable weather conditions and if the host plant is merely a shrub or a small tree.

The problem of correct identification is perhaps a thorny issue as these hemi-parasitic plants are easily affected by weather and ecological factors. The common practice is the use of a group term 'mistletoe' for all these plants just as the Yoruba, for example, refer to them whether they are semi-woody, green, brown, perennial or bushy as 'afomo onisana,' because the 
flowers resemble a match stick, sometimes yellow-flowered with red or purple corolla tips such as in P.capitata or purpleflowered with yellow corolla tips as in some other mistletoes.

The information here sets to appraise the medicinal values of some species of Globimetula, Phragmanthera, Agelanthus and Tapinanthus (Loranthaceae) in the West African sub-region, and this is based on the information available in the literature on the subject.

\section{Biology \\ Spread of Mistletoes}

It is widely accepted that the spread of mistletoe species is by seed dispersal and this is usually mediated by birds that thrive on mistletoe fruit or host through faecal excretions or regurgitations (Burkill, 1985, Karunaichamy et al., 1999). In Southern India, Tickel's Flowerpecker, also called the Pale-billed flower pecker, was reported to facilitate seed dispersal of Dendrophtoe falcata among neem (Hambali, 1977). This view was corroborated by Weston et al. (2012) who recently studied the dependence on Sunbird pollination for fruit set in three West African montane mistletoe species, Globimetula braunii, Agelanthus brunneus and A. djurensis growing in Ngel Nyaki Forest Reserve in Nigeria. Weston and his collaborators observed that all the three mistletoes were self compatible but not capable of autonomous self fertilisation. They noted that the pollination assemblage comprised four species of Sunbirds, Cyanomitris spp, Cinnyris spp and small social Wasp (Vespinae), and also that whereas none of the mistletoes required birds for flower opening, each mistletoe species required Sunbirds for effective pollination and fruit set.

The above findings and views are supported by the presence of the same species of mistletoe growing on different hosts within the same vicinity. We have identified four different hosts - Cola nitida, Theobroma cacao, Spondias monbin, and Rauwolvia vomitoria for Globimetula cupulata - within the same vicinity and also the occurrence of the same species of mistletoe on the different aerial parts of the same host. We have found and counted about twenty five stands of the mistletoe Agelanthus brunneus (syn. Tapinanthus brunneus ) on a host, Citrus paradisi located in Obafemi Awolowo University Teaching and Research Farm Citrus plantation (OAU T\&R FARM). That Tapinanthus bangwensis had been found on 43 different hosts in 18 plant families (Burkill, 1985) and that Dendrophthoe falcata (L. f) Ettingsh (Loranthaceae), the most common of all the mistletoes that occur in India, has about 401 plant hosts and possesses remarkable potentials as a medicinal plant (Pattanayak and Sunita, 2008) showed that some species of the mistletoe may not be selective in the choice of hosts, while other species seem to be restricted to particular hosts, particularly fruit-bearing plants. Otherwise, it would appear difficult to explain why the mistletoe, Agelanthus brunneus, could be found on only two (one sample each) out of the seven or more stands of Citrus limon located in the OAU T\&R FARM. An example of this was observed earlier; Tapinanthus globiferus was found to parasitise 17 different ornamental, woody and orchard trees in the Middle Awash Valley in Ethiopia while another parasitic plant, Odontella schimperi, was found only on two species of trees Casuarina equistifolia and Dobera glabra (Zewdie and Eshetu, 1993).

\section{Host/plant relationship}

These hemi-parasitic plants have caused the host plants many biological effects, chief among which is salt imbalance. A formulated hypothesis is that these hemi-parasites (Loranthaceae) would contribute to decrease the salt content in parasitised host boughs particularly those bearing fruits (Dibong et al., 2010). To verify this hypothesis, the authors studied and assessed the response of five host species (Citrus maxima, Manikara zapota, Persia Americana, Psidium guajava and Theobroma cacao) of the hemi-parasite Phragmanthera capitata to sodium and potassium distribution in the plant tissues. They found that $P$. capitata reduceds the $\mathrm{Na}^{+}$concentrations in the aerial parts of infected host trees and maintained the salt level low in photosynthetic organs. High concentrations of $\mathrm{K}^{+}$were observed in the leaves of the non-infected host branches of three hosts, Citrus maxima, Manikara zapota and Psidium guajava. On the other hand, the parasite leaves of Theobroma cacao had the higher concentrations of $\mathrm{K}^{+}$than those of host roots, leaves of non-parasite host branches, the parasitised leaves of the host and the parasite suckers. The authors (Dibong et al., 2010) concluded that Loranthaceae could contribute to decrease the content of salt on parasitised host boughs and then on branches bearing fruits. This phenomenon could explain why the quality of fruits in fruit-bearing plant hosts should decline due to the parasitism of Loranthaceae.

\section{Ethnopharmacology}

The ethnomedicinal uses of mistletoes had, for a very long time, been in the hands of very few herbal practitioners who claimed a general use to counter sorcery and magical powers, to treat mental conditions, sterility, and health problems associated with urino-genital system, rheumatism and pain. These hemi-parasitic plants, mistletoes of the Loranthaceae and Viscaceae, are widely used in various cultures in almost every continent to treat various ailments including hypertension, cancer, and diabetes, or used as a diuretic agent (Burkill, 1985; Adodo, 2004; and Jadhav et al., 2010). For example, the tea made from Loranthaceae spp. is believed to cure bone fracture and body pain (Ken'ichi, M. et al., 2006). Remedies for tumour (Tanachaa) in South-western Ethiopia were reported to be prepared by crushing fresh leaves of Tapinanthus globiferus (A.Rich.) Tiegh. and mixed with cold water to be administered orally (Yineger and Yewhalaw, 2007). Also in the Ebolowa region of Cameroon, one handful of the fresh leaves of Tapinanthus globiferus is usually mixed with one handful of the root bark of Boswella odorata, the ingredients are macerated in $5 \mathrm{~L}$ of local beer and one glassful is taken twice a day for two weeks to cure syphilis (Noumi and Eloumou, 2011). In 
Saudi Arabia, fresh stems of Tapinanthus globiferus (local name, Hadhal) are given orally to all types of livestock for the treatment of fever and removal of placenta after parturition (Sher and Alyemeni, 2011).

Various preparations of Viscum album (as injectable mistletoe extracts) are already articles of commerce and are sold across Europe with the labels of Helixor, Iscador, Abnobaviscum and as fermented V. album (Matthes et al., 2005, Urech et al., 2005 and Kienle and Kiene, 2007), and are used to treat epilepsy, infertility, hypertension and arthritis. Powdered leaves of a mistletoe (or mistletoes also identified as Viscum album!) and purportedly sourced off cocoa, avocado and citrus - a product of Natural Health Product Services Limited - are sold across Southern Nigeria under the trade name 'NAHEPS' Mistletoe Tea. NAHEPS claims that the tea is traditionally used to promote good health as it enhances natural body immunity.

Mistletoes are now known as "cure all" and have been found beneficial as a drug/remedy for more than twenty health problems (Adodo, 2004). It is usual to prepare the leaves of a single species of mistletoe alone in medicine but more often, the leaves of two or more species of mistletoes which are thought to be the same but are only differentiated by the nature of their hosts are harvested and processed for use together. This is because the efficacy of drug preparations produced are thought to be dependent on the host plant(s) and that mistletoes harvested on certain hosts are suited for the treatment or cure of a particular health problem.

The biology of the Loranthaceae remains largely unclear. The relationships between Loranthaceae and their hosts have been a subject for study in the past and will continue to be for the lesser-known African mistletoes particularly. The sucker ensures the continuity of the major elements, $\mathrm{Na}^{+}, \mathrm{K}^{+}, \mathrm{Ca}^{2^{+}}, \mathrm{Mg}^{2+}$ etc., of the two plants and enables the diversion of water and nutritive substances from the plant to the parasite (Bannister et al., 2002). Apart from minerals, organic acids and pigments, how much of the host plant constituents may be transported to the mistletoe and vice versa? It was once observed, for instance, that medicinal properties of Dendrophthoe falcata may vary in effects respective to different hosts it establishes a relation with (Mallavadhani et al., 2006). Wang et al. (2008) reported that Taxillus spp Loranthaceae exhibited potent inhibition on fatty acid synthase and that the difference in host plants did not affect markedly on the inhibitory ability of the parasite. In practical terms, herb sellers and herbalists have always recommended mistletoes harvested on particular hosts in the management or treatment of certain health problems (Adodo, 2004; Burkill, 1985). This may not have a scientific backing as constituents of Korthalsella japonica did not change or disappear irrespective of its host trees (Fukunaga et al., 1989).

A recent ethnopharmacological study (Dibong et al., 2009) carried out on the hemi-parasites growing in Cameroon sought information on the biology, ecology and the medicinal uses of the Loranthaceae. The authors used a structured questionnaire to interview 150 active traditional healers and reported that the herbalists recognised the existence of only one species which they later identified as Phragmanthera capitata. (This species, the authors identified as "cancer" in the French language). The authors also reported that $82 \%$ of the healers recommended P. capitata for the treatment of some 22 different diseases, including hypertension, hypotension, irregular menstruations, menopause, convulsions, diabetes, rheumatism related pains, epilepsy, kidney and chronic muscular pains. Fresh leaves are usually used in infusion or macerated, and the dosage is not usually standardised. It is noteworthy from available reports that the uses of $P$. capitata are similar to those reported for European mistletoes, particularly Viscum album and that the Loranthaceae is generally recognised in ethnomedicine.

\section{The Chemistry of the Mistletoes}

Not much information is readily available on the chemistry of many African mistletoes. The two chemical information readily available include (1), the structural identification of a polysaccharide in Phragmanthera capitata leaf cell wall and (2), the isolation, purification and the study of metabolic activities of a peptide from the fresh leaves of Phragmanthera incana. Apart from the above chemical reports, the information given in Table 1 below on the Loranthaceae and the Viscaceae relates to some information available in the literature for Viscum album and other European and Asian mistletoes.

The most distinctive constituents of most European and Asian mistletoes are proteins, the viscotoxins, lectins and carbohydrates. The small molecular weight compounds include flavonoids and phenylpropanoids of varying structural types, and they contribute to the anti-oxidative properties of the various Loranthaceae extracts examined. There have been two reports listed here of a peptide and a carbohydrate from the genus Phragmamthera in the African Loranthaceae. Many reports of the presence of smaller molecular weight compounds, alkaloids, flavonoids, tannins and other plant constituents in the African Loranthaceae have not been substantiated by isolation and proper identification. There is, therefore, a lot more to be done to fully appreciate the chemical constituents' profile of the African mistletoes.

\section{Pharmacological Effects of Mistletoe Extracts}

The biological effects of the extracts of Viscum album and other mistletoes and their influence on quality of life in cancer patients are well known (see Table 2). Wang et al. (2008) found that the reversible inhibitory ability of the extracts from Taxillus chinensis (DC) Dancer Loranthaceae was nearly 400-fold stronger than that from the Viscaceae and that the medicinal herb with high inhibitory ability on fatty acid synthase (FAS) significantly reduced the body weight and food intake of mice by oral administration. The medicinal herbs from the family Loranthaceae were thus found suitable as botanical sources of parasitic loranthus for weight control and that herbs from the genus Taxillus Tieghem were the best in both reversible and irreversible inhibition. 
Table 1: The Chemistry of Mistletoes

\begin{tabular}{|c|c|c|c|}
\hline Plant & Active constituents & Parts used & References \\
\hline Phragmanthera capitata & $\begin{array}{l}\text { Pectin and hemicellulosic } \\
\text { polysaccharides }\end{array}$ & Leaf & Aboughe Angone et al., 2009 \\
\hline Phragmanthera incana & Phragmanthin & Fresh leaf & Fasanu and Oyedapo, 2008 \\
\hline Viscum album & $\begin{array}{l}\text { Glycoproteins; mistletoe lectins I, II, and } \\
\text { III, proteins; viscotoxins and } \\
\text { polysaccharides; galacturonan, } \\
\text { arabinogalactan }\end{array}$ & Leaf & $\begin{array}{l}\text { Obata, } 1941 \\
\text { Samuelsson and Pettersson, } 1971 \\
\text { Schaller et al.,1998 } \\
\text { Margaret Loeper, } 1999 \\
\text { Deliorman et al., } 2000\end{array}$ \\
\hline $\begin{array}{l}\text { V.articulatum and } \\
\text { Helianthus elastica (Ders.) }\end{array}$ & Triterpenoids and polyphenolics & Leaf & Jadhav et al., 2010 \\
\hline V. angulatum & $\begin{array}{l}\text { Phenolic glycosides (pinocembrin 7-O- } \\
\text { apiosyl }(1 \rightarrow 5 \text { ) apiosyl }(1 \rightarrow 2)-\beta \text {-D- } \\
\text { glucopyranoside, } 2^{\prime}, 3^{\prime}, 4^{\prime}, 3^{\prime}- \\
\text { tetramethoxy- } 1,3 \text {-diphenylpropane } 5^{\prime}, 4^{\prime}- \\
\text { di-O- } \beta \text {-D-glucopyranoside and } \\
\text { rhamnocitrin 3-O-apiosyl }(1 \rightarrow 5) \\
\text { apiosyl }(1 \rightarrow 2) \text { - }[\alpha-\mathrm{L}- \\
\text { rhamnopyranosyl }(1 \rightarrow 6)]-\beta-D- \\
\text { glucopyranoside). Viscumneoside, } \\
\text { naringenin and homoeriodictyol }\end{array}$ & Leaf & Lin et al., 2002 \\
\hline Loranthus tanakae Fr. Et Sav. & $\begin{array}{l}\text { Four anti-tumour flavonoid } \\
\text { rhamnopyranosides identified as } \\
\text { rhamnetin 3-O- } \alpha \text {-L-rhamnoside, quercetin } \\
\text { 3-O- } \alpha \text {-L-rhamnoside, rhamnocitrin 3-O- } \alpha \text { - } \\
\text { L-rhamnoside and kaempferol 3-O- } \alpha \text {-L- } \\
\text { rhamnoside. }\end{array}$ & Leaf & Kim et al., 2004 \\
\hline Scurrula ferruginea Danser. & $\begin{array}{l}\text { Three cyto-toxic natural flavonols- } \\
\text { quercetin, quercitrin and } 4 \text { "-O-acetyl- } \\
\text { quercitrin }\end{array}$ & Leaf & Lohézic-Le Dévéhat et al., 2002 \\
\hline Taxillus yadoriki Danser, & $\begin{array}{l}\text { Hyperin and quercitrin with fatty acids, } \\
\text { phytosterol and phytosterol glucoside. }\end{array}$ & Leaf & Fukunaga et al., 1989 \\
\hline Taxillus kaempferi Danser & $\begin{array}{l}\text { Fatty acids, phytosterol, } \\
\text { phytosterolglucoside, quercetin, avicularin } \\
\text { and taxillusin; also quercitrin and hyperin }\end{array}$ & Leaf & Fukunaga et al., 1989 \\
\hline Korthalsella japonica Engler & $\begin{array}{l}\text { Chrisoeriol-4'-O-glucoside, fatty acids, } \\
\text { phytosterol, oleanolic acid and } \\
\text { phytosterolglucoside. Chrysoeriol-4'-O- } \\
\text { glucoside was a common constituent of } \\
\text { this mistletoe irrespective of the host. }\end{array}$ & Leaf & Fukunaga et al., 1989 \\
\hline $\begin{array}{l}\text { Dendrophthoe falcate (L. f) } \\
\text { Ettingsh (Loranthaceae) }\end{array}$ & 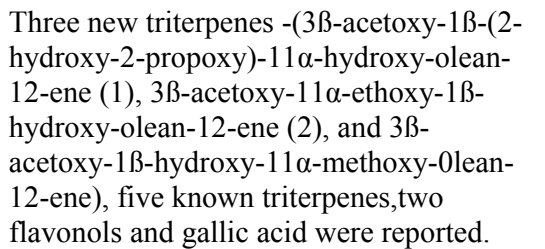 & Leaf & $\begin{array}{l}\text { Mallavadhari, } 2006 \\
\text { Pattanayak et al., 2008, 2012, }\end{array}$ \\
\hline
\end{tabular}


Metabolic studies of Phragmanthin isolated from Phragmanthera incana (Loranthaceae) in Sprague-Dawley rats showed that it caused significant reduction in the levels of plasma inorganic phosphate, haemoglobin, activities of L-alanine aminotransferase and alkaline phosphatase, muscle glycogen and blood sugar. It also exhibited a slight elevation of the levels of plasma L-aspartate amino-transferase activity and creatinine (Fasanu and Oyedapo, 2008).These pharmacological effects and other biological assets of mistletoe extracts are summarised in the Table 2 below:

Table 2: Pharmacological Effects of Mistletoe Extracts

\begin{tabular}{|c|c|c|c|}
\hline Plants & Parts Used & Pharmacological Uses & References \\
\hline \multirow[t]{4}{*}{ Viscum album } & Leaf & Anti-cancer & $\begin{array}{l}\text { Zee-Cheng, 1997; Mahfouz et al., 1998; Mengs } \\
\text { et al., 2002; Cebović et al., 2008; Kienle et al., } \\
\text { 2009; Kienle \&d Kiene, 2007, } 2010 .\end{array}$ \\
\hline & Leaf & $\begin{array}{l}\text { Reported hypoglycaemic properties } \\
\text { Histopathological studies on the pancreas } \\
\text { showed a restorative effect of the extract on } \\
\text { pancreatic islet cells. }\end{array}$ & Edem, 2009 \\
\hline & Leaf & $\begin{array}{l}\text { G. cupulata was listed as an anti- } \\
\text { Hypertensive and hypoglycaemic plant. }\end{array}$ & Talha et al, 2011 \\
\hline & Leaf & Anti-diabetic and hypotensive & $\begin{array}{l}\text { Lutomski, 1986, Swanson-Flatt et al., 1989; } \\
\text { Adsersen and Adsersen, 1997, Gray and Flatt, } \\
1999 \text { and Orhan et al, } 2005 .\end{array}$ \\
\hline $\begin{array}{l}\text { Taxillus chinensis } \\
\text { (DC) Dancer } \\
\text { Loranthaceae }\end{array}$ & Leaf & $\begin{array}{l}\text { Herb with high inhibitory ability on fatty } \\
\text { acid synthase (FAS) }\end{array}$ & Wang et al., (2008) \\
\hline $\begin{array}{l}\text { Phragmanthera } \\
\text { incana (Loranthaceae) }\end{array}$ & Leaf & $\begin{array}{l}\text { Exhibits a slight elevation of the levels of } \\
\text { plasma L-aspartate amino-transferase } \\
\text { activity and creatinine }\end{array}$ & Fasanu and Oyedapo, 2008 \\
\hline Globimetula braunii & Leaf & $\begin{array}{l}\text { Oxytocic properties } \\
\text { Leaf extract showed oxytocic properties } \\
\text { compared with that of a standard uterine } \\
\text { stimulant oxytocin and uterine smooth } \\
\text { muscle antagonists, atropine and salbutamol }\end{array}$ & Le and Zam, 2008 \\
\hline Globimetula braunii & Leaf & $\begin{array}{l}\text { Laxative properties } \\
\text { Fresh leaf extract of the plant exhibits } \\
\text { laxative properties compared with a } \\
\text { reference substance (Senna) }\end{array}$ & Fred-Jaiyesimi et al, 2008 \\
\hline Globimetula braunii & Leaf & $\begin{array}{l}\text { Anti-oxidative Properties } \\
\text { Ethyl acetate fraction caused a significant } \\
\text { increase }(\mathrm{p}<0.05) \text { in the activities of } \\
\text { superoxide dismutase, catalase, glutathione } \\
\text { peroxidase and malonydialdehyde (MDA) } \\
\text { levels, while the level of triacylglycerol } \\
\text { decreased }(\mathrm{p}<0.05) \text { compared to control. }\end{array}$ & Okpuzor et al., 2009 \\
\hline $\begin{array}{l}\text { Globimetula } \\
\text { cupulatum }\end{array}$ & Leaf & $\begin{array}{l}\text { Globimetula cupulatum and } 9 \text { other selected } \\
\text { medicinal plants widely used in } \\
\text { ethnomedicine were analysed for their } \\
\text { phytochemical constituents and } \\
\text { antioxidants. Free radical scavenging } \\
\text { activities (FRSA) was reported to have the } \\
\text { highest hydroxyl radical scavenging activity }\end{array}$ & Akinmoladun et al., 2010 \\
\hline
\end{tabular}


Globimetula cupulata Leaf

Tapinanthus bagwensis

Tapinanthus dodoneifolius

Tapinanthus globiferus

Globimetula braunii
Leaf
Tapinanthus
sessilifolius

Leaf of $63.84 \pm 0.97 \%$. The extracts demonstrated high lipid peroxidation inhibitory activity and possessed significant antioxidant and radical scavenging activities.

Hypoglycaemic properties

The authors concluded that their result supported the traditional use of the leaf of the plant in the management of diabetes mellitus when compared with streptozotocin and metformin as reference drugs

Anti-inflammatory Properties

Patrick-Iwuanyanwu et al., 2010

The authors concluded that the extract of the butanol fraction possessed antiinflammatory effects in experimental animals

Leaf Leaf showed significant anti-diabetic properties

Antimalarial Activities

Leaf methanol extracts of Tapinanthus sessifolius showed a mild to weak antiplasmodial activity in the in vitro assay while it had intrinsic antimalarial properties that were done dependent in vivo)

\section{Antimicrobial Properties}

The authors found a wide spectrum of antimicrobial activities against certain multiple drug resistant bacterial and fungal isolates of farm animals including the inhibition of the growth of Bacillus sp. Agrobacterium tumefaciens, Escherichia coli, Salmonella sp., Proteus sp., and Pseudomonas sp.

The authors found that the crude methanolic and chloroform extracts had growth inhibitory effects on Bacillus aureus, Providencia stautii, Escherichia coli, Pseudomonas aeruginosa, Staphylococcus aureus and Klebsiella pneumonia but did not inhibit the growth of Salmonella typhi, Aspergillus niger and Candida albicans.

The authors also found the methanol extract bacteristatic and bactericidal; it also compared well with standard drugs, gentamycin and rifanpicin, used as reference drugs in the study.

Lipid Lowering Activities

The authors concluded that the results obtained indicated antilipemic and hypocholesteremic activities of G. braunii, indicative of possible cardio-protective potential in normo and hypercholesteremia situations.
Ojewole and Adewole, 2007

Ekhaise et al, 2011

Okpako and Ajaiyeoba, 2004

Deeni and Sadiq, 2002

Ndukwe et al., 2001

Erukainure et al., 2010 


Tapinanthus $\quad$ Leaf
globiferus
globiferus
The authors concluded that the leaf extract lowered total cholesterol, LDL-cholesterol and triglycerides, and suggested its use in the management of hypertension.
Akanji et al., 2009

Cook et al, 1998

\section{Toxicological studies on Mistletoe Leaf Extracts}

Mistletoes are generally considered to be toxic probably because some of their constituents such as lectins are cytotoxic to certain organisms. Crude mistletoe fruit or herb is used to make tea to treat hypertension at a dosage of $10 \mathrm{~g} /$ day (Drugs.com). Toxicity could be a function of the specie of mistletoe; whereas the fruit of $D$. falcata tasted sweet and was consumed as food (Mallavadhani et al., 2006), the fruits of most African mistletoe were described as toxic berries (Adodo, 2004) which could lead to vomiting, hypotension, cerebral dysfunctions and death by a heart attack if ingested in large numbers (Dibong et al., 2009). The results of the various feeding experiments as well as the toxicity tests carried out suggest that the crude mistletoe leaf extracts were non-toxic to laboratory animals.

Okpuzor et al. (2009) investigated the safety of Globimetula braunii leaf extracts in rats. It was evaluated for possible hepatic and haematological effects. The rats were fed with various extracts of the plant at a dose of $200 \mathrm{mg} / \mathrm{kg}$ body weight for 14 days. They observed significant increases $(\mathrm{p} \leq 0.05)$ in packed cell volume $(\mathrm{PCV})$ and haemoglobin $(\mathrm{Hb})$ in the rats treated with $\mathrm{CHCl}_{3}$, EtOAc and Water fractions. The red blood cell $(\mathrm{RBC})$ count increased $(\mathrm{p}<0.05)$ after the administration of $\mathrm{CHCl}_{3}$ and EtOAc fractions, while white blood cell $(\mathrm{WBC})$ count increased $(\mathrm{p}<0.05)$ in the crude and all its fractions except $\mathrm{BuOH}$.

Liver function enzymes were also assessed. Significant decreases $(p<0.05)$ in the activities of aspartate amino transferase (AST) and alanine amino transaminase (ALT) enzymes were observed in rats treated with $\mathrm{CHCl}_{3}$ fraction, while there was elevation in the activity of ALT in the $\mathrm{BuOH}$ group. Though they recorded no difference $(\mathrm{p}>0.05)$ in enzyme activities in the $\mathrm{MeOH}$ fraction, the administration of other fractions to the rats, led to increases $(\mathrm{p}<0.05)$ in the activities of both enzymes. Total and direct bilirubin showed increases $(p<0.05)$ in EtOAc and hexane fractions, while only direct bilirubin increased $(p<0.05)$ in the crude fraction. They concluded that G.braunii $\mathrm{CHCl}_{3}$ fraction had an influence on haematological functions and liver enzyme levels in rats.

In another study, the crude $\mathrm{MeOH}$ extracts of Tapinanthus bangwensis and its various fractions were evaluated for their hepatoprotective potential against $\mathrm{CCl}_{4}$-induced hepato-toxicity in Wistar albino rats (Patrick-Iwuanyanwu et al., 2010). The activities of the marker enzymes, ALT, AST and ALP and bilirubin were highest in rats treated with $\mathrm{CCl}_{4}$ alone. The administration of the extract $(400 \mathrm{mg} / \mathrm{kg} \mathrm{BW})$ for 7 days, significantly $(\mathrm{p} \leq 0.05)$ decreased the activity of marker enzymes and bilirubin. Total protein concentration increased significantly $(\mathrm{p} \leq 0.05)$. These extracts also decreased the concentration of thiobarbituric acid reactive substances (TBARS) which indicated a reduction in lipid peroxidation. Histopathological examination of hepatocytes of rats that received the extracts showed normal architecture, whereas rats treated with $\mathrm{CCl}_{4}$ alone were characterised by necrosis of the liver. The crude $\mathrm{MeOH}$ extract did not show any mortality even at a dose of $2000 \mathrm{mg} / \mathrm{kg} \mathrm{BW}$. They concluded that the title plant possessed strong anti-oxidant properties and hepatoprotective potentials against $\mathrm{CCl}_{4}$-induced hepatotoxicity in rats

\section{Conclusion}

Mistletoes possess many ethnomedicinal assets. The importance of the mistletoes in ethnopharmacology is now well known and this is supported by the scientific information recorded in the pharmacological studies of some of the crude or purified extracts. In addition to the above, it is now appreciated that mistletoes are therapeutically useful in oxidative stress induced health problems, are potential sources of natural anti-oxidants, and have great potentials as medicinal agents.

\section{Acknowledgements}

We acknowledge the wonderful contributions of the staff of IFE Herbarium and Professor E. O. Iwalewa who read through this manuscript and made suggestions. We also appreciate all those great minds whose research work(s) have been reviewed. Your contributions are acknowledged. 


\section{References}

1. Aboughe Angone, S., Bardor, M., Nguema-Ona, E., Rihouey, C., Ishii, T., Lerouge, P., Driouich, A. (2009). Structural characterization of cell wall polysaccharides from two plant species endemic to Central Africa, Fleurya aestuans and Phragmanthera capitata. Carbohydrate polymers 75(1); 104-109.

2. Adodo, A. (2004). Nature Power, A Christian Approach to Herbal Medicine. Benedictine Publication Nigeria, $3^{\text {rd }}$ Edition, Edo State pgs; 103-111.7th Printing by Generation Press Ltd, Surulere, Lagos.

3. Adsersen, A. and Adsersen, H. (1997). Plants from Reunion Island with alleged antihypertensive and diuretic effects, an experimental and ethnobotanical evaluation. J. Ethnopharmacol 58; 189-206.

4. Akanji. M. A., Ayorinde, B. T., Yakubu, M. T., (2009). Anti-lipidaemic potentials of aqueous extract of Tapinanthus globiferus leaves in rats. RPMP Vol 25- Chemistry and Medicinal Value, Eds. V.K. Singh and J. N. Govil pg 1-9.

5. Akinmoladun, A. C., Obuotor, E. M.,Farombi, E. O., (2010). Evaluation of antioxidant and free radical scavenging capacities of some Nigerian Indigenous Medicinal Plants. Journal of Medicinal Food 13(2); 444-451.

6. Bannister, P., Graham, L., Strong, Inge A., (2002).Differential accumulation of nutrient elements in some new mistletoes and their hosts. Functional Plant Biology 29 (11); 1309-1318.

7. Begho, E. R., Omokhafe, K. O., Omo-Ikerodah, E. E. and Akpaja, E.O. (2007). Some observations on the fruit set and incidence of Mistletoes on rubber trees in Nigeria. Am-Eurasian J. Sustain. Agric. 1(1); 13-18.

8. Bright, E. O. and Okusanya, B. A.,(1998). Infestation of economic plants in Badeggi by Tapinanthus dodoneifolius (DC) Danser and Tapinanthus globiferus (A. Rich) Van Tiegh. Nigerian J. of Weed Science 11; 51-56.

9. Burkill, H.M., (1985), The useful Plants of West Tropical Africa. Royal Botanical Gardens, Kew. Vol.3 (families J-L) pgs; 548-560.

10. Cebovic, T., Spasic, S., Popovic, M. (2008). Cytotoxic effects of the Viscum album L. extract on Ehrlich tumour cells in vivo. Phytother, Res. 22(8); 1097-1103.

11. Cook, J. A., Van der Jagt, D. J., Dasgupta, A., Mounkaila, G., Glew, R.S., Blackwell, W., Glew, R. H., (1998). Use of the Trolox assay to estimate the antioxidant content of seventeen edible wild plants of Niger. Life Sci. 63(2); 105-110.

12. Deeni, Y. Y., Sadiq, N. M., (2002). Antimicrobial properties and phytochemical constituents of the leaves of African mistletoe (Tapinanthus dodoneifolius (DC) Danser (Loranthaceae): an ethnomedicinal plant of Hausaland, Northern Nigeria. J. Ethnopharmacol. 83(3); 235-240.

13. Deliorman, D., Calis, I., Ergun, F. (2000) Studies on the vascular effects of the fractions and phenolic compounds isolated from Viscum album ssp album, J. Ethnopharmacol. 72: 323-329.

14. Dévéhat, F. L-L., Tomasi, S., Fontanel, D., Boustie, J. (2002). Flavonoids from Scurrula ferruginea Danser (Loranthaceae). Z. Naturforsch 57c, 1092-1095.

15. Dibong, S. D., Engone, O.N.L., Din, N., Priso, R. J., Taffouo, V. O. D., Fankem, H., Salle, G., Missoup, A. D., Boussim, I. J. and Amougou, A. (2009). An assessment on the uses of Loranthaceae in ethnopharmacology in Cameroon; A case study made in Logbessou, North of Douala. J Med Plants Res 3(8); 592-595.

16. Dibong, S. D., Taffouo, V. D., Ndiang, Z., Ngotta, B., Mony, R., Engone Obiang, N. L., Din, N., Priso, J. R., Issaka, B. J. and Amougou, A. (2010). The study of sodium and potassium distribution in five host species of Phragmanthera capitata (Sprengel) S. Balle in the littoral region of Cameroon. J. Appl. Biosci 30: 1839-1844.

17. Edem, D.O., (2009). Effect of aqueous extracts of leaves of Globimetula cupulata (DC) Van Tieghem in Normoglycemic Rats. The internet J. Alt. Med. 8(1); 1-6.

18. Ekhaise, F. O., Kayode, A. M., Sylvester, U., (2011), Evaluation of the methanolic extract of mistletoe (Tapinanthus bangwensis) leaves grown on orange trees for the phytochemical properties and its physiological effects on streptozotocin-induced diabetes mellitus in laboratory animals. Global J. Pure and Applied Sci. 17(3); $267-271$.

19. Erukainure, O. L., Abovwe, J. A., Adefegha, A. S., Egwuche, R. U., Fafunso, M. A., (2011). Antilipemic and hypocholesteremic activities of Globimetula braunii in rats. Exp. Toxicol. Pathol. 63(7-8); 657-661.

20. Fasanu, P. O., Oyedapo, O. O., (2008). Phragmanthin-peptide from fresh leaves of African mistletoe (Phragmanthera incana): purification and metabolic activities. In; Recent Progress in Medicinal Plants 19: Phytopharmacology and Therapeutic Values 1(J. N. Govil, V. K. Singh and R. Bhardwaj Eds.) 28; pg 39-47.

21. Fred-Jaiyesimi, A., Onabanjo, T., Ademuyiwa, O. (2008). Phytochemical and laxative studies of Globimetula braunii (Engle) van Tiegh growing on Cola acuminata (Schott \& Endl). Afr. J. Tradit. Complement Altern. Med. 5(4); 419-420.

22. Fukunaga, T., Nishiya, K., Kajikawa, I., Takeya, K., Itokawa, H., (1989). Studies on the constituents of Japanese mistletoes from different host trees and their antimicrobial and hypotensive properties. Chem Pharm. Bull. (Tokyo) 37(6); 1543-1546.

23. Gill, L. S., and Onyibe, H. I., (1990). Mistletoes on rubber trees in Nigeria. Haustorium 23; 1-2.

24. Gray, A. M., and Flatt, P.R., (1999). Insulin-secreting activity of the traditional anti-diabetic plant V. album (mistletoe) . J. Endocrinol. 160; 409-414.

25. Hambali, G. G., (1977). On mistletoe parasitism. Proceedings of the $6^{\text {th }}$ Asian Pacific Weed Science Society Conference, Indonesia pp. 58-66.

26. Jadhav, N., Patil, C. R., Chaudhari, K. B., Wagh, J. P., Surana, S. J., and Jadhav, R. B., (2010). Diuretic and natriuretic activity of two mistletoes species in rats. Phcog Research 2(1); 50-57.

27. Jiofack, R. T., Dondjang. J. P., Nkongmeneck, B. A., (2010). The Loranthaceae of the Bafou area in Cameroon; identification, distribution, biology and eradication strategies. In: Systematics and Conservation of African Plants, 
Proceedings of the $18^{\text {th }}$ AETFAT Congress, Yaounde, Cameroon $26^{\text {th }}$ February-2 ${ }^{\text {nd }}$ March, 2007. (Burgt, X. van der; Maesen, J. van der; Onana, J. M., Editors). Pp 229-235.

28. Karunaichamy, K., Arp, K. Paliwal, A. (1999). Biomass and nutrient dynamics of mistletoe (Dendrophtoe falcata) and neem (Azadirachta indica) seedlings. Current Sci. 76(6); 840-843.

29. Ken'ichi, M., Kazuhiro, N., Norimasa, N.,Dawa, D., Laximi, T., Atsushi, W., Fumi, M., Toshiro, B., Gaku, M. (2006). Report of investigation for Wild Edible Plants and their Traditional Knowledge in Bhutan. J. Faculty Agric. Shinshu University 42 (1-2); 37-47.

30. Kienle, G. S., Glockmann, A., Schink, M., Kiene, H. (2009). V. album L. extracts in breast and gynaecological cancers; a systematic review of clinical and preclinical research. J.Exp. Clin. Cancer res. 28; 79.

31. Kienle, G. S., Kiene, H., (2007). Complementary cancer therapy; a systematic review of prospective clinical trials on anthroposophic Mistletoe extracts. Eur. J. Med. Res. 12; 103-119.

32. Kienle, G. S., Kiene, H., (2010). Review article: Influence of V. album L. (European mistletoe) extracts on quality of life in cancer patients; a systematic review of controlled clinical studies. Integr. Cancer Ther. 9(2); 142-157.

33. Kim,Y-K., Kim, Y-S., Choi, S. U., Ryu, S-Y. (2004). Isolation of flavonoid rhamnosides from Loranthus tanakae and cytotoxic effect of them on Human Tumor Cell Lines. Arch. Pharm. Res. 27(1); 44-47.

34. Le,O., Zam, N., (2008) Oxytocic properties of the aqueous extract of Globimetula braunii (Loranthaceae). Pak. J. Pharm. Sci. 21(4); 356-360.

35. Lin, J-H., Chlou, Y-N., Lin, Y-L., (2002). Phenolic glycosides from V. angulatum J. Nat. Prod. 65(5); 638-640.

36. Lutomski, J. (1986). Evaluation of the hypotensional activity of some mistletoe (V. album L.) drugs. Int. Meeting on V. album, Heidelberg. Clin. Trials J. 23; 345-358

37. Mahfouz, M. M., Ghaleb, H. A., Zawawy, A., scheffer, a., (1998). Significant tumour reduction, improvement of pain and quality of life and normalization of sleeping patterns of cancer patients treated with a high dose of mistletoe. Ann Oncol. 9(2); 129-138.

38. Mallavadhani, U. V., Narasimhan, K., Venkata, A., Sudhakar, S., Mahapatra, A., Li, W., Breemen, R. B. V., (2006). Three new pentacyclic triterpenes and some flavonoids from the fruits of an Indian Ayurvedic Plant Dendrophthoe falcata and their estrogen receptor binding activity. Chem. Pharm. Bull. 54 (5); 740-744.

39. Margaret Loeper, MS., (1999). Mistletoe (Viscum album L.) Longwood Herbal Task Force (http://www.mep.edu/herbal/default.htm).

40. Matthes, H., Schad, F., Buchward. D., Schenk, G., (2005). Endoscopic ultrasound-guided fine needle injection of $V$. album L. (mistletoe; Helixor M) in the therapy of primary inoperable pancreas cancer; a pilot study. Gastroenterol. 128 (4 Suppl.2); 433, T 988.

41. Mengs, U., Gothel, D., Leng-Peschlow, E. (2002). Mistletoe extracts standardized to mistletoe lectins in oncology. Review on current status of preclinical research. Anticancer Res. 22; 1399-1405.

42. Ndukwe, I. G., Amupitan, J. O., Ashonibare, O. E., (2001). Phytochemical analysis and antimicrobial activity screening of the crude extracts from the aerial parts of Tapinanthus globiferus. Journal or book name, Nig. J. Chem. Res.6: 43-46.

43. Noumi, E., Eloumou, M. E. R., (2011). Syphilis ailment; Prevalence and herbal remedies in Ebolowa subdivision (South region, Cameroon). Int. J. Pharm. Biomed. Sci. 2(1); 20-28.

44. Obata, Y. (1941). The components of V.album III. The unsaponifiable matter of the leaves, the so-called $\alpha$-viscol and $\gamma$ viscol. J. Agric. Chem. Soc. (Japan) 17; 784-786.

45. Ojewole, J.A.O., Adewole, S. O., (2007). Hypoglycemic and hypotensive effects of Globimetula cupulata (DC) Van Tieghem (Loranthaceae) aqueous leaf extract. Cardiovasc. J. S. Afr. 18(1); 9-15.

46. Okpako, L. C., Ajaiyeoba, E., O., (2004). In vitro and in vivo antimalarial studies of Striga hermonthica and Tapinanthus sessilifolius extracts African J. of Medicine and Medical Sciences. 33(1); 73-75.

47. Okpuzor, J., Ogbunugafor, H., Kareem, G.K., (2009). Antioxidative properties of ethyl acetate fraction of Globimetula braunii in normal albino rats. J. Biol. Sci. 9(5); 470.

48. Okpuzor, J. Ogbunugafor, H. A., Kareem, G. K.,(2009). Hepatic and hematologic effects of fractions of Globimetula braunii in normal albino rats. Excli; Journal 8; 182-189.

49. Orhan, D. D., Asian, M., Sendogolu, N., (2005). Evaluation of the hypoglycaemic effect and antioxidant activity of three V. album subspecies (European mistletoe) in streptozotocin- diabetic rats. J. Ethnopharmacol. 98; 95-102.

50. Overfield, D., Riches, C., Samoah, A.M., Sarkodie, O., Baah, F., (1998). A farming system analysis of the mistletoe problem in Ghanian Cocoa. Cocoa Grower's Bulletin 51; 42-50.

51. Parker, C., Riches, C. R., (1993). Parasitic weeds of the World; Biology and Control, CAB International, Wallingford pg. 332.

52. Patrick-Iwuanyanwu, K. C., Onyeike, E. N., Wegwu, M. O., (2010). Anti-inflammatory effect of crude methanolic extract and fractions of African mistletoe Tapinanthus bangwensis (Engl. \& K. Krause) on wistar albino rats. Der Pharmacia Lettre 2(6); 76-83.

53. Patrick-Iwuanyanwu, K. C., Onyeike, E. N., Wegwu, M. O., (2010).Hepatoprotective effects of methanolic extract and fractions of African mistletoe Tapinanthus bangwensis (Engl. \& K. Krause) from Nigeria. Excli Journal 9; 187-194.

54. Pattanayak, S. P., Sunita, P.,(2008). Wound healing, anti-microbial and antioxidant potential of Dendrophthoe falcata (L. f) Ettingsh. J. of Ethnopharmcol. 120; 241-247.

55. Pattanayak, S. P., Mazumder, P. M., Sunita, P. (2008). Dendrophtoe falcate (L. f); a concensus review. Phcog Reviews 8: 359-368. 
56. Pattanayak, S. P., Mazumder, P. M., Sunita, P. (2012). Total Phenolic Content, Flavonoid content and in vitro antioxidant activities of D. falcate (L. f) Ettingh. Res. J. Med. Plant 6(2): 136-148 920120.

57. Polhill, R., Wiens, D. (1998). Mistletoe of Africa. The Royal Botanic Garden, Kew, U. K. pg 370.

58. Samuelsson, G., Pettersson, B. M., (1971). The amino acid sequence of viscotoxin B from the European mistletoe (Viscum album L., Loranthaceae). Eur. J. Biochem. 21 (1); 86-89.

59. Schaller, G., Urech, K., Grazi, G., Giannattasio, M. (1998). Viscotoxin composition of the three European subspecies of V. album. Planta Med. 64(7); 677-678.

60. Sher, H., Alyemeni. M. N., (2011). Pharmaceutically important plants used in traditional system of Arab medicine for the treatment of livestock ailments in the kingdom of Saudi Arabia. African Journal of Biotechnology 10(45); 91539159.

61. Sridhar, T. S., Rao, V. R. (1978), Dendrophthoe falcata, a menace to fruit orchards. Current Sci. 38; 908.

62. Swanson-Flatt, S. K., Day, C., Bailey, C. J., Flatt, P. R., (1989). Evaluation of traditional plant treatments for diabetes; Studies in streptozotocin diabetic mice. Acta Diabetologica Latina 26; 51-55.

63. Talha, J., Priyanka, M. Akanksha,A. (2011). Hypertension and herbal plants. International Research J. of Pharm. (IRJP), 2(8); 26-30.

64. Wang, Y., Deng, M., Zhang, S-Y., Zhou, Z-K., Tian, W-X., (2008). Parasitic loranthus from Loranthaceae rather than Viscaceae potently inhibits fatty acid synthase and reduces body weight in mice. J. Ethnopharmacol. 118(3); 473-478.

65. Weston, K. A., Chapman, H. M., Kelly, D., Moltchanova, E. V., (2012). Dependence on Sunbird pollination for fruit set in three West African montane Mistletoe species. Journal of Tropical Ecology, 28; 205-213.

66. Urech, K., Scher, J. M., Hostanska, K., (2005). Apoptosis inducing activity of viscin, a lipophilic extract from V. album L. J. Pharm. Pharmacol. 57; 101-109.

67. Yineger, H., Yewhalaw, D., (2007). Traditional medicinal plant knowledge and use by local healers in Sekoru District, Jimma Zone, Southwestern Ethiopia. Journal of Ethnobiology and Ethnomedicine 3; 24.

68. Zee-Cheng, R., (1997). Anticancer research on Loranthaceae plants. Drugs Future. 22; 519-530.

69. Zewdie, K., Eshetu, T., (1993). Preliminary observation on feasibility of mechanical control of parasitic plants on trees. Proceedings of the $7^{\text {th }}$ Annual Conference of the Ethiopian Weed Science Committee, Rezene Fesehale (IAR,(Ethiopia): EWSC, 1993. Pg.41-42. 